\title{
A contabilidade no planejamento das finanças pessoais: Um estudo de caso com os acadêmicos do curso de Ciências Contábeis da UESPI de Picos
}

Accounting in personal finance planning: A study case with academic students from the Accounting Degree at UESPI of Picos

La contabilidad en la planificación de las finanzas personales: Un estudio de caso con académicos del grado de Contabilidad de la UESPI de Picos

Recebido: 06/06/2021 | Revisado: 12/06/2021 | Aceito: 15/06/2021 | Publicado: 01/07/2021

Elvis Gomes Marques Filho

ORCID: https://orcid.org/0000-0003-2681-6094 Universidade Estadual do Piauí, Brasil

E-mail: elvisfilho@pcs.uespi.br

Roméria Moura Silva

ORCID: https://orcid.org/0000-0001-5388-7221 Universidade Estadual do Piauí, Brasil

E-mail: romeriasilva@ aluno.uespi.br

Ítalo Jansen de Sousa Feitosa

ORCID: https://orcid.org/0000-0003-3420-1217 Universidade Federal do Piauí, Brasil

E-mail: italofeitosa03@gmail.com

Aline Maria Barbosa Lopes

ORCID: https://orcid.org/0000-0002-0536-1249 Universidade Estadual do Piauí, Brasil

E-mail: alinemblopes@gmail.com

Luciano Silva Figueiredo

ORCID: https://orcid.org/0000-0002-6564-2720 Universidade Estadual do Piauí, Brasil

E-mail: lucianosilva@pcs.uespi.br

Janaína Alvarenga Aragão

ORCID: https://orcid.org/0000-0002-7146-2718 Universidade Estadual do Piauí, Brasil E-mail: janainaalvarenga@pcs.uespi.br Carlos Victor Brito Saraiva

ORCID: https://orcid.org/0000-0001-7641-4363

Universidade Federal do Maranhão, Brasil

E-mail: victor.brito.saraiva@gmail.com

\begin{abstract}
Resumo
Existe uma grande dificuldade por parte dos indivíduos em controlar-se financeiramente e fazer uso de um Planejamento Financeiro em suas Finanças Pessoais. Nesta perspectiva surgiu a concepção desse trabalho, que teve como objetivo principal analisar se os acadêmicos do curso de Bacharelado em Ciências Contábeis da Universidade Estadual do Piauí, campus de Picos, aplicam as técnicas contábeis no planejamento das suas finanças pessoais, bem como identificar o perfil socioeconômico dos discentes, verificando como os mesmos organizam suas finanças pessoais e como foram educados financeiramente, averiguando se existe um planejamento financeiro pessoal a fim de melhorar a utilização da renda obtida e por fim identificar a importância da Contabilidade e as demonstrações contábeis dentro das finanças pessoais dos discentes do curso supramencionado. A metodologia utilizada inicialmente no trabalho foi bibliográfica, através de livros e artigos que tratam sobre o assunto, posteriormente foi realizada uma pesquisa de campo através de questionário com perguntas fechadas sobre a temática apontada. Por meio dessa pesquisa, através da parte teórica e das respostas analisadas do questionário todos, os objetivos foram alcançados, ao concluir-se que os alunos apresentam um bom nível de conhecimento sobre o tema abordado.
\end{abstract}

Palavras-chave: Finanças pessoais; Planejamento financeiro; Contabilidade pessoal.

\begin{abstract}
There is a great difficulty in persons regarding their control of finances and making good use of Financial Planning in their Personal Finances. Taking it into account, we acknowledge the importance of this paper, which has as main objective to analyze whether academics of the Bachelor Degree of Accounting at the State University of Piauí, campus Picos, apply accounting techniques when planning their personal finances, as well as to identify the profile of socioeconomic status of the academics, establishing how they organize their personal finances and how they were
\end{abstract}


financially educated, assessing whether there is a personal financial planning in order to improve the use of their income and, finally, to identify the importance of Accounting and the financial planning in the personal finances of these students. The methodology initially used in this work was bibliographic, through books and academic papers which dealt with the subject, secondly, a field research was carried out through a survey with objective questions about the theme. By using this research, the theoretical component and the analyzed responses of the survey, the paper's objectives were fulfilled, concluding that the students present a good level of knowledge on the theme.

Keywords: Personal finance; Financial planning; Personal accounting.

\section{Resumen}

Existe una gran dificultad para que las personas se controlen financieramente y hagan buen uso de una Planificación Financiera en sus Finanzas Personales. Desde esta perspectiva surgió la concepción de este trabajo, que tuvo como objetivo principal analizar si los académicos de la carrera de Licenciatura en Contabilidad de la Universidad Estatal de Piaú, campus de la ciudad de Picos, aplican técnicas contables en la planificación de sus finanzas personales, así como identificar el perfil de la situación socioeconómica de los estudiantes, verificando cómo organizan sus finanzas personales y cómo se educaron financieramente, verificando si existe una planificación financiera personal con el objetivo de mejorar el uso de los ingresos obtenidos y finalmente identificar la importancia de los estados contables y financieros dentro de finanzas personales de los alumnos del citado grado superior. La metodología utilizada inicialmente en el trabajo fue bibliográfica, a través de libros y artículos que abordan el tema, posteriormente se realizó una investigación de campo a través de un cuestionario con preguntas cerradas sobre el tema mencionado. A través de esta investigación, a través de la parte teórica y las respuestas analizadas del cuestionario, se alcanzaron todos los objetivos, concluyendo que los estudiantes presentan un buen nivel de conocimiento sobre el tema abordado.

Palabras clave: Finanzas personales; Planeamiento financeiro; Contabilidad personal.

\section{Introdução}

As Finanças estão presentes diariamente na vida das pessoas. Segundo Cherobim \& Espejo (2011), Finanças Pessoais é a ciência que estuda a aplicação de conceitos financeiros nas decisões da vida financeira de um indivíduo ou família. Já para Ferreira (2006), Finanças Pessoais são definidas como o processo de planejar, organizar e controlar nosso dinheiro. Isso significa determinar antecipadamente o que fazer com o dinheiro, determinar os planos necessários para alcançar os objetivos definidos, como também, organizar os hábitos de consumo e investimentos, assegurando que os resultados se ajustem ao que foi planejado.

De acordo com Macedo Junior (2013), o Planejamento Financeiro é um instrumento que possibilita a organização das finanças pessoal e familiar. Nesse contexto, surge a importância da aplicação do planejamento financeiro nas finanças pessoais, pois planejar é controlar ou gerenciar seu dinheiro com o objetivo de atingir a satisfação pessoal e ter controle das suas despesas. $\mathrm{O}$ autor ressalta ainda que possuir um planejamento e controle de suas finanças é essencial na vida financeira das pessoas, assim como manter a disciplina necessária para o alcance dos objetivos, principalmente para aqueles que buscam garantir tranquilidade econômico-financeira.

Dessa forma, a Contabilidade pode auxiliar no planejamento das finanças pessoais e na tomada de decisão, através das demonstrações contábeis que podem ser usadas no planejamento e controle das finanças do patrimônio pessoal, como Balanço Patrimonial, Demonstrações do Resultado do Exercício, Demonstração do Fluxo de Caixa e Orçamento, que podem ser utilizadas para esses fins, e para o gerenciamento da vida financeira. Possibilitando a qualquer pessoa compreender e relacionar seus bens e direitos com suas obrigações, usando as demonstrações contábeis no planejamento financeiro (Iudícibus, et al., 2010).

Diante disso, a pesquisa pretendeu responder à seguinte problemática: quais técnicas contábeis são usadas pelos acadêmicos do curso de Ciência Contábeis no planejamento financeiro de suas finanças pessoais?

De maneira geral, o presente trabalho se justifica pela busca de esclarecer aos acadêmicos do curso de Ciências Contábeis da UESPI, campus Professor Barros Araújo, Picos-PI, a importância que se deve dar ao planejamento das suas finanças pessoais e a forma como a Contabilidade pode ajudá-los a organizar sua vida financeira, com análise de dados que possibilite a qualquer pessoa entender e relacionar seus bens e direitos com suas obrigações, e através do planejamento poupar para o crescimento do seu patrimônio. 
Já a justificativa acadêmica consiste no fato de existir poucos trabalhos sobreo assunto relacionado no acervo da biblioteca da universidade, além disso, em relação aos acadêmicos de contábeis, é importante para que os mesmos apliquem seus conhecimentos dentro do planejamento financeiro pessoal. Desta forma, o presente trabalho servirá como um ponto de referência para contribuir e estimular o conhecimento sobre finanças pessoais e contribuirá para a comunidade acadêmica e científica em futuros trabalhos.

O trabalho tem como objetivo geral analisar a aplicação das técnicas contábeis dentro do planejamento das finanças pessoais dos acadêmicos de Ciências Contábeis da UESPI de Picos; e como objetivos específicos identificar o perfil socioeconômico dos discentes, verificando como os mesmos organizam suas finanças pessoais e se foram educados financeiramente, averiguar se existe um planejamento financeiro pessoal a fim de melhorar a utilização da renda obtida, e identificar a importância da Contabilidade e as demonstrações contábeis dentro das finanças pessoais dos discentes do curso supramencionado.

\section{Finanças Pessoais}

As finanças estão presentes diariamente na vida das pessoas, a todo momento o indivíduo tem que tomar decisões financeiras que terão impacto na vida pessoal. Portanto, o tema Finanças Pessoais é atual e aborda o comportamento e os conceitos financeiros das pessoas em lidar com dinheiro que está ligado no gerenciamento correto de suas finanças. Aquele que é capaz de planejar, organizar e controlar sua vida financeira também é capaz de definir de modo antecipado qual será o destino do seu dinheiro (Ferreira, 2006).

Gitman (2004) define finanças como “a arte e a ciência da gestão do dinheiro". Para o mesmo, praticamente todas as pessoas ou organizações recebem ou levantam, gastam ou investem dinheiro, de alguma forma as finanças atingem diretamente na vida pessoal. Portanto na tomada de decisões e controle financeiro é fundamental saber lidar com as finanças pessoais.

Para Bodie \& Merton (2002), finanças é a ciência que estuda a forma como as pessoas, individualmente ou em grupos, alocam seus recursos ao longo do tempo. Existe um conjunto de conceitos financeiros que ajudam as pessoas a guardar recursos ao longo dos anos e modelos de gerenciamento para melhor avaliar as alternativas, tomar decisões e implantá-las.

Para Cherobim \& Espejo (2011), as finanças pessoais abrangem o estudo financeiro levando em consideração a fase de vida em que se encontra o indivíduo, podendo interferir no planejamento financeiro pessoal, para que isso não aconteça é necessário que se estabeleçam metas e que haja um controle das despesas. Conforme o autor, a vida financeira pessoal é um reflexo de quem somos

Por exemplo, Kotler \& Keller (2006) afirmam que as decisões financeiras são levadas por características pessoais, como a idade e preparação na fase de vida, ocupação, situação econômica, personalidade, autoimagem, estilo de vida e valores. Os autores complementam que o casamento, o nascimento dos filhos, o divórcio, a viuvez, dentre outros, devem ser levados em consideração, pois essas transições e mudanças podem alterar as decisões financeiras.

Segundo Pires (2006), as Finanças Pessoais têm por objeto de estudo e análise as situações de financiamento das aquisições de bens e serviços necessários aos prazeres e desejos individuais. Já o objetivo do estudo é assegurar que as despesas do indivíduo ou família sejam sustentadas por recursos próprios, que as despesas sejam distribuídas proporcionalmente, sendo inevitável a utilização de recursos de terceiros, que as metas pessoais possam ser alcançadas e que o patrimônio pessoal cresça ao máximo. Para alcançar os objetivos individuais, é necessário ter um maior conhecimento financeiro sobre as finanças pessoais, tornando possível compreender os recursos, bem como serão investidos e gastos.

\subsection{Educação Financeira}

Educação Financeira é o processo de desenvolvimento da capacidade integral do ser humano de viver bem, fisicamente, emocionalmente, intelectualmente, socialmente e espiritualmente. Essa é uma forma de estar aberto ao processo 
constante de aprendizagem e sempre buscar conhecimento através de fontes de informação, como sites, chats, fóruns via internet, jornais, livros, revistas, consultorias entre outros, acessando sempre que precisar (Pereira, 2005).

Para Domingos (2013), a Educação Financeira vai muito além de registros, estar educado financeiramente é saber o que fazer com o dinheiro, já que ele é um meio para realizar sonhos e não um fim. É preciso entender que quando adquirimos os hábitos corretos em relação ao uso do dinheiro, quando o respeitamos e valorizamos, conseguimos administrar de maneira correta e ser felizes em nossas vidas financeiras.

Segundo Frankenberg (1999), a educação recebida dos pais ou responsáveis, as experiências financeiras e o meio em que vivemos podem influenciar na maneira de administrar o dinheiro. O autor leciona também que a herança genética adquirida dos nossos pais é importante no planejamento financeiro, ressalvando que a mesma educação recebida nem sempre será a administrada igual entre irmãos. Isso porque cada indivíduo tem uma maneira de lidar com o dinheiro, assim como o modo de ser na vida.

Para Cerbasi (2015), é importante que a Educação Financeira se inicie dentro de casa, desde a infância até a fase adulta, através de incentivos econômicos feitos com práticas cotidianas. Portanto, a educação financeira tem uma fundamental importância em cada etapa da vida, além de ressaltar também os fatores externos, que podem influenciar na formação negativa do comportamento.

Segundo Massaro (2015), os principais benefícios da Educação Financeira é viver com menos preocupação e mais qualidade de vida, ter capacidade de tomar decisões e poder planejar o futuro. Logo, aqueles que são educados financeiramente têm maior facilidade de administrar seu próprio dinheiro, tomam decisões no momento certo, planejam melhor a vida financeira pessoal e familiar.

As vantagens são inúmeras para aqueles que são educados financeiramente, pois sabem fazer o gerenciamento de suas finanças, obtendo informações essenciais para realizar um planejamento financeiro adequado às suas necessidades.

\section{Planejamento Financeiro}

Para iniciar o Planejamento Financeiro, é necessário primeiramente seguir de maneira sistemática na tomada de decisões em relação à vida financeira. É provável que decisões de impacto sejam menos constantes e que o indivíduo seja menos influenciado por fatores externos. Diante disso, é fundamental que o indivíduo esteja comprometido com os objetivos propostos para o atingimento das metas escolhidas, pois a falta de comprometimento com o planejamento implica a não realização das metas, ocasionando um desperdício de tempo e trabalho (Sousa, et al., 2018).

De acordo com Gtiman (2004), o Planejamento Financeiro é importante nas operações da empresa para atingir os objetivos, de modo a orientar, coordenar e controlar as iniciativas da empresa, através de argumentos que proporcionam uma estrutura para compreender a extensão do processo de planejamento, podendo gerar a maximização de sua ação, coordenação de inúmeras atividades da empresa para obter uma boa administração nas atividades financeiras.

Existem diversos acontecimentos que podem ocorrer pela falta de planejamento ou então em virtude de um planejamento mal executado. Para Cherobim \& Espejo (2011), no Planejamento Financeiro existe o propósito para o futuro, no qual são determinados os objetivos futuros que desejam ser alcançados, pretendendo tornar realidade tanto na vida pessoal como na empresarial o que antes era objetivo e sonho.

Segundo Frankemberg (1999), Planejamento Financeiro é feito a fim de alcançar metas com o intuito de que o indivíduo gaste menos dinheiro do que ganha, ajudando a obter um controle desejável e a compreender qual a prioridade pessoal. Com o objetivo de estabelecer um método para acumulação de bens e valores, construir o patrimônio pessoal, que leva a alcançar a principal meta, que é a tranquilidade e segurança financeira.

Para Macedo Junior (2013), Planejamento Financeiro é o processo de administrar o dinheiro com o objetivo de alcançar a 
satisfação pessoal, permitindo chegar às necessidades e aos objetivos no decorrer da vida. Para que os objetivos propostos sejam alcançados por cada indivíduo ou entidade, torna-se indispensável o uso de um bom planejamento financeiro. Ainda segundo o autor, o planejamento deve funcionar igual um mapa de navegação para a vida financeira, mostrar onde você está, aonde quer chegar e que caminhos traçar para ter uma vida próspera financeiramente e cheia de realizações.

\subsection{Planejamento Financeiro Pessoal}

No Planejamento Financeiro Pessoal é estabelecida a forma como serão viabilizados os recursos financeiros para realizar os objetivos. É de suma importância uma análise sincera sobre a realidade financeira pessoal e familiar, quando for necessário. Estas são informações importantes para a elaboração de um orçamento pessoal que possibilite qualidade de vida atual (no presente) e próspera (no futuro) (Cherobim \& Espejo, 2011).

Para Ferreira (2006), planejar finanças pessoais significa determinar previamente qual objetivo que devemos traçar com nosso dinheiro e quais as metas necessárias para alcançá-los no decorrer da vida. Planejamento Financeiro Pessoal nada mais é que o processo de administrar seu dinheiro com o objetivo de atingir a satisfação pessoal (Macedo Junior, 2013).

Halfeld (2007) afirma que a regra que norteia o plano financeiro pessoal é básica, por exemplo: não gastar mais do que se ganha é o primeiro passo do planejamento. Enxergar a situação financeira é de suma importância ao organizar e planejar suas receitas e despesas. O planejamento financeiro, portanto, começa com a elaboração do orçamento e em seguida com o fluxo de caixa, onde são descritas todas as relações financeiras, as receitas e despesas do período.

De acordo com Cerbasi (2015), qualquer planejamento não obterá êxito caso não seja acompanhado de equilíbrio orçamentário, isso quer dizer que gastar menos do que se ganha e investir a diferença é indispensável para que os objetivos sejam alcançados. Primeiramente, precisa ter conhecimento detalhado de seus gastos mensais e utilizar essa informação dentro do seu planejamento, usando metas para viabilizar recursos financeiros pessoais de qualidade.

Assim, a forma mais simples de planejar é lançar os gastos em uma planilha, comparando os gastos atual com os de outros meses atrás, buscando sempre otimizar, para que possa ver os gastos menos prioritários e quais as prioridades de consumo, reduzindo, assim, os não-prioritários, e atingindo sua meta planejada (Cerbasi, 2015).

Segundo Pires (2007), os instrumentos básicos para o Planejamento das Finanças Pessoais são o orçamento e o fluxo de caixa. Já para Massaro (2015), o Planejamento Financeiro pode ser executado através do patrimônio, das receitas, das despesas e do fluxo de caixa. Dessa forma, traz a importância da Contabilidade no Planejamento das Finanças Pessoais, podendo ser usadas algumas demonstrações, que consolidarão a compreensão da lógica das Finanças Pessoais.

\section{Contabilidade Pessoal}

Antes de adentrar a Contabilidade Pessoal, precisa-se compreender o que é a Contabilidade. Segundo Montoto (2015), a Contabilidade é considerada uma Ciência Social, que estuda o patrimônio, tanto de uma entidade econômicaadministrativa, quanto de pessoas físicas ou jurídicas. Seu principal objetivo é obter registros dos fenômenosque afetam a sua situação patrimonial e financeira, tendo por objeto de estudo o patrimônio de entidades de fins lucrativos ou não. Para Ribeiro (2010), a principal finalidade da Contabilidade é fornecer informações de ordem econômica e financeira sobre o patrimônio.

Para Silva \& Tristão (2009), a Contabilidade Pessoal é uma organizaçãofinanceira do patrimônio das pessoas físicas, seja ela aplicada nos bens, direitos, obrigações ou nas finanças pessoais. É o registro de todas as operações financeiras realizadas por um indivíduo, usadas no controle e gerenciamento das finanças pessoais, pois através das ferramentas contábeis se torna possível calcular a situação econômica, financeira e patrimonial de uma pessoa, buscando melhor entender as fontes e as aplicações de recursos, como todas as transações financeiras.

Porém, são poucos os escritórios que trabalham com a Contabilidade Pessoal, assim como para pessoas jurídicas, a 
Contabilidade Pessoal é o registro detodas as operações financeiras realizadas por uma pessoa (Pires, 2006).

Segundo Marion (2018), a necessidade da Contabilidade para Pessoa Física se deve ao fato da tomada de decisão, dentro ou fora da empresa, que visa fornecer informações da situação financeira com base nos fatos ocorridos no patrimônio. Diante disso, a coleta de dados proporciona a oportunidade de administrar a própria vida financeira, observando possibilidades de economizar e guardar recursos (dinheiro), para futuros investimentos.

Tendo em vista os aspectos observados, Montoto (2015), diz que fazemos contabilidade naturalmente todo dia em nossa vida, nos preocupando com o controle de nosso patrimônio e sempre apurando resultado. Em nosso dia a dia, sempre há apreensão com as despesas e receitas pessoais e familiares. O objetivo é saber sea cada mês será conseguido superar as despesas com as receitas, examinando o resultado. De acordo com o autor, o uso da Contabilidade se vê no dia a dia das pessoas, pois todos os trabalhadores ou qualquer pessoa ao efetuarem transações simples para saber quanto receberão ou calcular o quanto gastaram na semana ou ao final de um mês, estão fazendo ou usando a Contabilidade.

Portanto, a Contabilidade pode auxiliar as pessoas físicas a se organizarem financeiramente, fazendo com que estas busquem melhores alternativas na utilização de seus recursos e possibilitando também uma análise dos dados, permitindo a qualquer pessoa entender e relacionar seus bens e direitos com suas obrigações. Para que alcance o sucesso, o indivíduo deve aprender a conciliar os conhecimentos contábeis e financeiros, para que se possa quantificar, analisar e equilibrar seus ativos, passivos e patrimônio líquido pessoal (Silva \& Tristão, 2009).

\subsection{A importância da Contabilidade em Finanças Pessoais}

Gallagher (2008) afirma que nada adianta ter saldo positivo se a pessoa não sabe desfrutar desse dinheiro, ou seja, não sabe quando ou em quê investi-lo ou até mesmo, quando não é um bom momento para fazer novas aquisições. Tendo em vista a importância da Contabilidade Pessoal no uso das finanças, sem qualquer controle e conhecimento delas trarão sérios prejuízos futuramente e o primeiro passo para a implementação do Planejamento Financeiro é mudar os hábitos pessoais.

A organização financeira e patrimonial segundo Halfeld (2007) pode influenciar diretamente na qualidade de vida de um indivíduo. Para a Pessoa Física a importância da Contabilidade se dá à medida que a mesma busca fornecer informações sobre a situação financeira com base nos fatos ocorridos no patrimônio pessoal, possibilitando a oportunidade de administrar a vida financeira, observando possibilidades de economias extras de recursos para futuros investimentos.

Ainda segundo o autor, para que a soma dos ativos seja maior que a soma dos passivos, é recomendado o controle do orçamento pessoal com o devido acompanhamento dos apontamentos da relação de todas as receitas líquidas ou brutas e de todas as despesas incorridas, sejam elas quais forem em determinado período.

Segundo Bodie \& Merton (2002), a maior parte das informações disponíveis para a tomada de decisão aparece nas demonstrações financeiras contábeis. Segundo o autor, elas amparam a três importantes funções econômicas, que são: proporcionar informações sobre a posição atual e o desempenho financeiro, usar para estabelecer metas de desempenho e proporcionar modelos para o planejamento financeiro.

\subsection{Demonstrações Contábeis nas Finanças Pessoais}

Segundo Pires (2006), as demonstrações contábeis são relatórios enviados por entidades empresariais, entidades sem fins lucrativos, e também pelo Governo. São elaboradas ao final de cada exercício social, registradas nos órgãos competentes e que devem estar à disposição do Fisco sempre que solicitado. De acordo com o autor, algumas demonstrações usadas na contabilidade podem também ser utilizadas na contabilização do patrimônio da pessoa física, com algumas modificações, sem que tome rumo diferente da sua estrutura.

De acordo com Marion (2018), a demonstração contábil no gerenciamento das Finanças Pessoais é extremamente 
eficiente, deve ser confeccionada de forma clara e de fácil entendimento, de acordo com cada indivíduo. Os relatórios contábeis devem ser demonstrados em valores de moeda e feitos mensalmente, lançando sempre todas as situações financeiras que tiver realizado no dia a dia, seja qual for esse gasto ou ganho.

Ainda segundo o autor, os relatórios contábeis para pessoa física demonstram: a relação do patrimônio bruto, as dívidas e obrigações contraídas no patrimônio, a situação líquida do patrimônio, os recebimentos ganhos pela pessoa física, a relação de gastos incorridos num determinado período e as origens e aplicações de recursos efetuados pelas pessoas físicas.

Esses relatórios contábeis para Pires (2006) são demonstrações financeiras utilizadas na tomada de decisão de qualquer pessoa física. As principais demonstrações financeiras contábeis que auxiliam as pessoas físicas no gerenciamento de suas finanças são a elaboração do Balanço Patrimonial, Demonstração do Resultado do Exercício, Demonstração do Fluxo de Caixa e o Orçamento.

\subsubsection{Balanço Patrimonial}

O Balanço Patrimonial tem por objetivo demonstrar a situação financeira, patrimonial e econômica de um ente ou entidade em determinado período (Marion, 2018). De acordo com o autor o Balanço Patrimonial é estruturado como mostra o Quadro 1 abaixo:

Quadro 1 - Estrutura básica do Balanço Patrimonial.

\begin{tabular}{|l|l|}
\hline \multicolumn{2}{|c|}{ BALANÇO PATRIMONIAL } \\
\hline $\begin{array}{l}\text { ATIVO } \\
\text { (Bens e Direitos) }\end{array}$ & $\begin{array}{l}\text { PASSIVO } \\
\text { (Obrigações) }\end{array}$ \\
\cline { 2 - 2 } & $\begin{array}{l}\text { PATRIMÔNIO LÍQUIDO } \\
\text { (Ativo - Passivo = PL) }\end{array}$ \\
\hline
\end{tabular}

Fonte: Marion (2018), com adaptações.

O balanço é composto por três elementos: Ativo, Passivo e Patrimônio Líquido. O Ativo é onde ficam localizados os bens e direitos em forma de liquidez, já o Passivo compreende as exigibilidades de obrigações e o patrimônio líquido representa a diferença entre o Ativo e o Passivo (Iudícibus, et al., 2010).

De acordo com autor, essa estrutura patrimonial é a mesma usada na gestão do patrimônio pessoal, o lado Ativo representará as aplicações de todos os recursos efetuados pela pessoa física em ordem de liquidez, como os seus bens, direitos, investimentos ou aplicações financeiras e suas reservas. Podendo ser classificados da seguinte maneira: Bens: veículos, imóveis, eletrodomésticos, etc.; Direitos: contas a receber; Investimentos ou Aplicações financeiras: ações, títulos públicos, etc.; Reservas: banco, caixa e outros. No lado passivo estão as obrigações que vêm em ordem de exigibilidade que são as contas contraídas no patrimônio pessoal, como: água a pagar, energia a pagar, empréstimos, etc. Logo, essas obrigações são recursos com terceiros que temos a obrigação de cumpri-las. A diferença dos bens e direitos (seus próprios recursos) menos as obrigações (dividas) de uma pessoa representam a situação líquida, num determinado período, ou seja, o seu patrimônio líquido, também chamado de reserva (dinheiro). Portanto, quanto mais Ativos e menos Passivos a pessoa tiver, melhor será sua vida financeira.

Temos assim de acordo com Santos (2009), um exemplo de Balanço Patrimonial para pessoa física: 
Quadro 2 - Modelo de Balanço Patrimonial pessoal.

\begin{tabular}{|l|l|}
\hline \multicolumn{1}{|c|}{ ATIVOS } & \multicolumn{1}{c|}{ PASSIVOS } \\
\hline Dinheiro disponível (Caixa, Banco) & Empréstimos bancários \\
Dinheiro em aplicações financeiras & Mensalidade escolar \\
Salários a receber & Planos de Plano de saúde \\
Aluguel a receber & Aluguel residencial \\
Pensão a receber & Impostos e taxas \\
Contas a receber (venda de patrimônio) & Financiamentos imobiliários \\
Bens primários (vestuário) & Financiamentos de veículos \\
Móveis (carro) & Aguá/Energia a pagar \\
Imóveis (casa) & Outros \\
Outros & \\
& \\
\cline { 2 - 2 } & PATRIMÔNIO LíQUIDO \\
& Resultados acumulados \\
\hline Total do ativo & Total do passivo e patrimonio líquido \\
\hline
\end{tabular}

Fonte: Santos (2009), com adaptações.

Identifica-se, de acordo com Tommasi \& Lima (2007), que o balanço patrimonial é um importante aliado no planejamento para a tomada de decisão, analisado através da situação financeira na qual o indivíduo se encontra, a capacidade de caixa disponível para quitar as dívidas, os investimentos realizados, as obrigações com terceiros em relação às dívidas, e a riqueza acumulada que será seu patrimônio líquido. Uma boa técnica para buscar o crescimento do patrimônio pessoal é investir em ativos que gerem retorno financeiro, para que o patrimônio trabalhe para a pessoa e não o contrário.

\subsubsection{Demonstração do Resultado do Exercício (DRE)}

A Demonstração do Resultado do Exercício é apresentada, em forma resumida, nas operações realizadas pela empresa, durante o exercício social, que tem como principal finalidade demonstrar o resultado líquido do período, seja ele lucro ou prejuízo acumulado (Iudícibus, et al., 2007).

De acordo com Marion (2018), nas finanças pessoais este relatório é representado em valores monetários, com todos rendimentos ou ganhos e pagamentos ou gastos envolvidos. Os rendimentos/ganhos são todos os recebimentos ganhos pela pessoa, como: salários, rendimentos de aplicações financeiras, recebimento da venda de algum patrimônio, aluguéis recebidos, ganhos em jogos etc. Os pagamentos/gastos são todos os pagamentos pagos pela pessoa, como: educação, investimentos culturais e intelectuais, alimentação, lazer, transporte, telefone, internet, água, energia etc.

Para Santos (2009), a DRE refere-se a todas as receitas (ganhos: entrada em dinheiro) e todas as despesas (gastos: saída de dinheiro), realizadas pela pessoa acumuladas no período, independentemente se foram recebidas ou pagas. É nela também que está expresso o valor do resultado líquido, que pode ser positivo ou negativo em um determinado período.

Temos assim de acordo com o autor, um exemplo de DRE usado no planejamento das finanças pessoais: 
Quadro 3 - Modelo de Demonstração de Resultado do Exercício pessoal.

\begin{tabular}{|l|}
\hline \multicolumn{1}{|c|}{ DRE } \\
\hline Receita Total \\
Receita da Atividade Profissional (salário) \\
Outras Receitas (aplicações financeiras, aluguel, pensão etc.) \\
(-) Despesa Total \\
Despesas Básicas (alimentação, educação, moradia, combustível etc.)Despesas Tributárias \\
(IPVA, IPTU) \\
Despesas Financeiras (juros)Outras \\
despesas \\
$=$ Resultado Antes do Imposto de Renda \\
(-) Imposto de Renda \\
$=$ Resultado Líquido
\end{tabular}

Fonte: Santos (2009), com adaptações.

Percebe-se que, por meio da DRE, a pessoa física tem acesso à apuração do resultado somente com as receitas e as despesas, sem considerar a movimentação de caixa. Facilitando a visualização das despesas tributárias, principalmente do Imposto de Renda e o resultado líquido do período, que poderá resultar em lucro/prejuízo ou ganho/perda do que foi recebido e também em relação aos gastos incorridos num determinado período. Essas informações são úteis na busca da redução de determinado gasto (Marion, 2018).

\subsubsection{Demonstração do Fluxo de Caixa (DFC)}

Vigorada pela Lei 11.638/2007, a Demonstração do Fluxo de Caixa é um relatório obrigatório para todas as entidades na gestão de qualquer organização ou empresa, assim como também nas Finanças Pessoais, para uma boa gestão do patrimônio pessoal é necessária a utilização desta demonstração (Iudícibus, et al., 2007).

Pires (2006) afirma que a demonstração do fluxo de caixa é importante nas finanças pessoais para que haja uma gestão adequada do patrimônio pessoal, pois são apresentados nessa demonstração todos os ganhos (entrada de dinheiro) e todos pagamentos (saída de dinheiro) efetuados em um determinado período de tempo.

O fluxo de caixa é a melhor ferramenta para controlar o dinheiro de forma detalhada, pois permite controlar as transações financeiras, ou seja, entradas e saídas de dinheiro em um determinado período que possibilita avaliar as disponibilidades financeiras e tomar decisões (Ferreira, 2006).

Para Iudicibus et al. (2007), ao analisar o fluxo de caixa, se o saldo for negativo, a pessoa tem gastado mais do que ganhado por mês, já se o saldo for positivo, o indivíduo está conseguindo pagar as suas despesas e indo bem no controle das suas finanças pessoais.

O fluxo de caixa é dividido em três grandes áreas: em Atividades Operacionais, Investimento e Financiamento. Os fluxos operacionais são as entradas e saídas diretamente ligadas à venda e produção de bens ou serviços. Os investimentos são a compra ou venda de imobilizado e participações em outras empresas. Os financiamentos são as captações de recursos de terceiros ou capital próprio (Gitman, 2004).

Temos assim de acordo com Ferreira (2006), um modelo de Fluxo de Caixa para a pessoa física: 
Quadro 4 - Modelo de Fluxo de Caixa pessoal.

\begin{tabular}{|l|l|l|l|}
\hline \multicolumn{3}{|c|}{ FLUXO DE CAIXAPESSOAL } \\
\hline OPERACIONAL & PROJETADO & REALIZADO & VARIAÇÃO \\
\hline $\begin{array}{l}\text { (+) RECEITAS } \\
\text { todas receitas ocorrida no mês } \\
(+) \text { Total das Receita }\end{array}$ & & \\
\hline $\begin{array}{l}\text { (-) DESPESAS } \\
\text { todas despesas ocorrida no mês } \\
\text { (-) Total de despesas }\end{array}$ & & & \\
\hline INVESTIMENTOS & & \\
\hline $\begin{array}{l}\text { (+) todos investimentos ocorrido nomês } \\
\text { (+) Total dos Investimentos }\end{array}$ & & & \\
\hline FINANCIAMENTOS & & \\
\hline $\begin{array}{l}\text { (-) todos financiamentos ocorridono mês } \\
\text { (-) Total dos financiamentos }\end{array}$ & & & \\
\hline SUPERÁVIT/DÉFICIT MENSAL & & \\
\hline
\end{tabular}

Fonte: Ferreira (2006), com adaptações.

Compreende-se que em um fluxo de caixa com Superávit, seu patrimônio estará com saldo positivo, e se resultou em um Déficit estará com saldo negativo. No entanto, fazer o acompanhamento do destino do dinheiro é a melhor forma de saber se está indo no caminho certo. Assim, através da elaboração do fluxo de caixa conseguirá ver os recursos disponíveis para os gastos ou investimentos (Ferreira, 2006).

\subsubsection{Orçamento Pessoal}

Para Tommasi \& Lima (2007), o Orçamento Pessoal é a primeira fase do Planejamento Financeiro Pessoal como instrumento auxiliar na administração das Finanças Pessoais, que busca entender como funciona o fluxo de receitas e despesas. Ajudando a ter uma vida financeiramente equilibrada possibilitando assim um maior controle da situação financeira. $\mathrm{O}$ autor alerta que devem tomar alguns cuidados antes de preparar o orçamento.

De acordo com Ferreira (2006), primeiro deve-se analisar as receitas para definir o quanto se pode gastar e depois as despesas. Portanto, receita é todo o dinheiro recebido no período, as despesas são todos os gastos ocorridos durante o mês. Ao fazer a análise entre receitas e despesas, se tiver sobrado dinheiro no resultado total do orçamento, então teremos um superávit, um saldo positivo, assim possibilitará que você faça um investimento, se desejar. No entanto, se as despesas forem maiores que as receitas, haverá um déficit, o que representará um saldo negativo no seu orçamento.

Segundo Tommasi \& Lima (2007), para começar um orçamento, deve-se descobrir primeiro o valor total da renda (Receitas), depois faz-se uma estimativa dos gastos, discriminando os gastos que se têm todos os meses (Despesas fixas, variáveis, extras e adicionais). Pode-se dividir também os gastos por categorias como alimentação, transportes, educação, saúde, etc. Assim, percebe-se quanto está sendo gasto em cada categoria, para que chegue ao levantamento dos saldos finais. A partir dessas informações, a pessoa poderá analisar a quantidade dos gastos em relação aos ganhos, se os saldos forem positivos indicam que os rendimentos são suficientes para cumprir com o pagamento de todos os gastos existentes.

Segundo o autor, quando apresentar um saldo negativo, deve-se descobrir qual a categoria de gastos que poderá ser melhor economizada para que chegue ao saldo positivo no final do mês. Estas informações são importantes para a gestão 
pessoal, pois a partir destas se buscam a otimização dos rendimentos, priorizando o pagamento dos gastos no orçamento pessoal.

Temos assim um modelo de planilha adaptada da BM\&FBOVESPA (2021), que pode ser utilizado no Orçamento Pessoal:

Quadro 5 - Modelo de planilha de Orçamento pessoal.

\begin{tabular}{|c|c|c|c|c|c|}
\hline \multicolumn{6}{|c|}{$\begin{array}{c}\text { PLANILHA } \\
\text { ORÇAMENTOPESSOAL }\end{array}$} \\
\hline & \multirow{5}{*}{ Receitas } & \multirow[b]{2}{*}{ Salário } & \multicolumn{3}{|c|}{ Meses de janeiro a dezembro } \\
\hline & & & & & \\
\hline & & Aluguel a receber & & & \\
\hline & & Horas extras & & & \\
\hline & & TOTAL & $\operatorname{xxxxxx}$ & $\mathbf{x x x x x x}$ & $\mathbf{x x x x x x}$ \\
\hline & & Ações & & & \\
\hline $\mathbf{I}$ & estimentos (Montante & Renda fixa & & & \\
\hline mensal des & ado aos & Previdência privada & & & \\
\hline & & TOTAL & $\mathbf{x x x x x x}$ & $\mathbf{x x x x x x}$ & $\mathbf{x x x x x x}$ \\
\hline & Categoria & Despesa & & & \\
\hline \multirow{10}{*}{$\begin{array}{l}\text { Despesas Fixas } \\
\text { (Aquelasque têm } \\
\text { o mesmo } \\
\text { montante) }\end{array}$} & \multirow{3}{*}{ Habitação } & Aluguel a pagar & & & \\
\hline & & Condomínio & & & \\
\hline & & Prestação da casa & & & \\
\hline & \multirow{2}{*}{ Transporte } & Prestação do carro & & & \\
\hline & & Seguro do carro & & & \\
\hline & Saúde & Plano de saúde & & & \\
\hline & Educação & Universidade Escola & & & \\
\hline & Impostos & IPTU / IPVA & & & \\
\hline & Outros & Seguro de vida & & & \\
\hline & \multicolumn{2}{|l|}{ TOTAL DESPESAS FIXAS } & $\mathbf{x x x x x x}$ & $\mathbf{X x x x x x}$ & $\overline{\mathbf{X x x x x x}}$ \\
\hline \multirow{13}{*}{$\begin{array}{c}\text { Despesas } \\
\text { Variáveis (Aquelas } \\
\text { que acontecem } \\
\text { todosos meses, mas } \\
\text { podemostentar } \\
\text { reduzir) }\end{array}$} & \multirow{4}{*}{ Habitação } & Luz & & & \\
\hline & & Água & & & \\
\hline & & Telefone / Celular & & & \\
\hline & & Gás & & & \\
\hline & \multirow{2}{*}{ Transporte } & Ônibus & & & \\
\hline & & Combustível & & & \\
\hline & \multirow{2}{*}{ Alimentação } & Supermercado & & & \\
\hline & & Padaria & & & \\
\hline & Saúde & Medicamentos & & & \\
\hline & \multirow{3}{*}{ Cuidados pessoais } & Cabeleireiro & & & \\
\hline & & Manicure & & & \\
\hline & & Academia & & & \\
\hline & \multicolumn{2}{|c|}{ TOTAL DESPESAS VARIÁVEIS } & $\mathbf{x x x x x x}$ & $\mathbf{x x x x x x}$ & xxxxxx \\
\hline \multirow{7}{*}{$\begin{array}{c}\text { Extras } \\
\text { (São as despesas } \\
\text { extra-ordinárias) }\end{array}$} & \multirow{2}{*}{ Saúde } & Médico & & & \\
\hline & & Dentista & & & \\
\hline & \multirow{2}{*}{ Manutenção/ prevenção } & Carro & & & \\
\hline & & Casa & & & \\
\hline & \multirow{2}{*}{ Educação } & Material escolar & & & \\
\hline & & Uniforme & & & \\
\hline & Total despesas extras & & $\mathbf{x x x x x x}$ & $\mathbf{x x x x x x}$ & $\mathbf{x x x x x x}$ \\
\hline & & Viagens & & & \\
\hline & Lazer & Restaurantes/bares & & & \\
\hline Adicionais & & Roupas & & & \\
\hline (Aquelasque & Vestuário & Calçados & & & \\
\hline não precisam & & Acessórios & & & \\
\hline & Outros & Presentes & & & \\
\hline & Total despesas adicionais & & $\mathbf{x x x x x x}$ & $\mathbf{X X X X X x}$ & $\overline{\mathbf{x x x x x x}}$ \\
\hline & & Receita & & & \\
\hline & & Investimentos & & & \\
\hline & & Despesas fixas & & & \\
\hline & Saldo & Despesas variáveis & & & \\
\hline & & Despesas extras & & & \\
\hline & & Despesas adicionais & & & \\
\hline & & Saldo total & XXXXXX & $\mathbf{X X X X X X}$ & Xxxxxx \\
\hline
\end{tabular}

Fonte: Adaptado de BM\&FBOVESPA (2021). 


\section{Metodologia}

Este capítulo tem por objetivo demonstrar os métodos e técnicas de pesquisa que foram utilizados na construção deste trabalho de conclusão de curso, assim como apresentar conceitos para cada um deles. Tem também como propósito explicitar a maneira como foram coletados, ordenados e analisados os dados.

De acordo com Martins \& Theóphilo (2009), a Metodologia é o aperfeiçoamento dos procedimentos e critérios utilizados na pesquisa, tendo como método o caminho para se chegar a determinado fim ou objetivo.

\section{1 Área de estudo}

A área de estudo desta pesquisa foi realizada na Universidade Estadual do Piaú, campus Professor Barros Araújo Picos, localizada na Rodovia 316, Bairro Altamira, CEP 64.602-000, a $310 \mathrm{~km}$ da capital Teresina-PI. Atualmente conta com 10 cursos presenciais, sendo 06 bacharelados e 04 licenciaturas, como também cursos à distância na modalidade Educação à Distância (EAD) através do PARFOR - Plano Nacional de Formação de Professores da Educação Básica (DTIC/UESPI, 2021).

\subsection{Enquadramento metodológico}

Para este trabalho, foi feito um estudo de caso com os acadêmicos do curso de Ciências Contábeis. Segundo Prodanov \& Freitas (2013), o estudo de caso possui uma metodologia de pesquisa classificada como aplicada, na qual se busca a aplicação prática de conhecimentos para a solução de problemas sociais.

A pesquisa realizada neste trabalho é classificada como exploratória e descritiva. De acordo com Gil (2008), a pesquisa exploratória tem como objetivo indicar maior familiaridade com o problema, para torná-lo mais explícito ou construir hipóteses. Já na pesquisa descritiva os fatos são observados, registrados, analisados, classificados e interpretados, sem que o pesquisador interfira sobre eles (Prodanov \& Freitas, 2013).

A pesquisa classifica-se como pesquisa de campo e bibliográfica, pois foi feita a coleta dos dados através de um questionário para que se alcançasse o objetivo deste trabalho como também a análise dos matérias já existentes sobre o assunto que foi exposto. Para Prodanov \& Freitas (2013), a pesquisa de campo é utilizada com o objetivo de conseguir informações acerca de um problema para o qual buscamos uma resposta. E para Gil (2008), a pesquisa bibliográfica é desenvolvida a partir de material já elaborado, constituído principalmente de livros e artigos científicos.

O presente estudo tem natureza quali-quantitativa, pois envolve análise de documentos existentes, levantamento e análise de dados numéricos através da aplicação do questionário e dos resultados obtidos dele. Visto que para Goldenberg (2004), tanto a pesquisa qualitativa quanto a quantitativa têm por preocupação o ponto de vista do indivíduo. A qualitativa é a comparação, por meio de materiais já existentes, buscando aprofundamento dos resultados do mesmo com o material coletado, já na quantitativa busca-se o levantamento de dados sobre determinado objeto de estudo baseado em questionário ou outras formas de entrevista.

\subsection{Coleta de dados}

A coleta de dados foi realizada através da aplicação de um questionário com 15 perguntas objetivas, referentes à temática estudada, para atender aos objetivos da pesquisa. Segundo Parasuraman (1991), um questionário é necessário para atingir os objetivos do projeto, através das questões e dos dados gerados. Embora o mesmo autor afirme que nem todos os projetos de pesquisa utilizam essa forma de instrumento de coleta de dados, o questionário é muito importante na pesquisa científica, especialmente nas Ciências Sociais.

O questionário foi elaborado através da ferramenta Google Forms utilizando a conta institucional do pesquisador, e enviado individualmente ao e-mail institucional de cada acadêmico de Ciências Contábeis de todos os blocos matriculados de 
2016.2 a 2020.1. A coleta foi realizada entre os dias 05 a 27 de janeiro de 2021 e recebida em qualquer horário.

\subsection{Análise de dados}

Para que fosse feita a análise da melhor forma possível, considerou-se o método da análise de dados, pois as respostas foram tabuladas e analisadas durante tratamento de dados através do Google formulário e do programa Excel. Os dados foram tratados de maneira que houve a compilação entre o referencial teórico escrito e as respostas obtidas.

\subsection{Aspectos ético-legais}

A presente pesquisa foi devidamente cadastrada na Plataforma Brasil, sendo esta a plataforma que unifica os trabalhos envolvendo direitos humanos e acompanha os trabalhos desde o projeto até sua finalização. Assim, priorizou-se um olhar de não julgamento, de respeito e singularidade, buscando fazer com que o trabalho fosse importante não só para o pesquisador mas também para os acadêmicos de Ciências Contábeis que participaram da pesquisa e também para todos que buscarem informações sobre o assunto na biblioteca da UESPI.

O trabalho foi cadastrado e protocolado na Plataforma Brasil e analisado pelo CEP/UFPI - Comitê de ética em Pesquisa da Universidade Federal do Piauí, campus Senador Helvídio Nunes de Barros - Picos, conforme a resolução 466/2012 do Conselho Nacional de Saúde. A coleta de dados só iniciou após a aprovação do referido CEP/UFPI. Para aplicação do questionário com os alunos da UESPI foi construído um Termo de Consentimento Livre e Esclarecido - TCLE, que foi enviado ao sujeito da pesquisa no início da coleta de dados, que, após o aceite do participante, uma cópia ficou com ele e a outra com o entrevistador.

\section{Resultados e Discussões}

Esta seção apresenta os resultados e discussões das análises realizadas a partir da coleta de dados, visando melhorar a aplicação do Planejamento Financeiro e a utilização das técnicas contábeis nas Finanças Pessoais a partir das informações coletadas através dos alunos.

A análise utilizada foi baseada através da análise de conteúdo de Bardin (2011). Segundo a autora, o termo análise de conteúdo significa um conjunto de técnicas de análise de comunicações visando a obter, por procedimentos sistemáticos e objetivos, a descrição do conteúdo das respostas, através de indicadores (quantitativos ou não) que permitem inferência. Indica que a utilização da análise de conteúdo prevê três fases fundamentais: a pré-análise, exploração do material e tratamento dos resultados. Na pré-análise é identificada como a fase de organização, envolve a leitura, ou seja, o primeiro contato com os documentos que foram submetidos à análise, a escolha deles, a formulação das hipóteses e objetivos, a elaboração e preparação formal do material. Na exploração do material, são escolhidas as unidades de codificação, adotando-se os seguintes procedimentos de codificação que compreendem a escolha de unidades de registroe por último o tratamento dos resultados, que é a inferência e interpretação dos resultados, que deverá ir além do conteúdo manifesto dos documentos, pois interessa ao pesquisador o conteúdo apreendido (Bardin, 2011).

Os resultados da pesquisa são apresentados em quatro tópicos: Perfil dos entrevistados, Conhecimento financeiro, Planejamento Financeiro e Utilização das técnicas contábeis no Planejamento Financeiro, divididas entre 15 questões, conforme mostra a Tabela 1. 
Tabela 1 - Divisão do questionário da pesquisa.

\begin{tabular}{ccc}
\hline Tópico & Temática do questionário & Quantidade deQuestões \\
\hline 1 & Perfil dos entrevistados & 6 \\
\hline 2 & Conhecimento financeira & 3 \\
\hline 3 & Planejamento financeiro & 3 \\
\hline 4 & Utilização das técnicas contábeis noplanejamento \\
& financeiro & 3 \\
\hline Total de questões & & $\mathbf{1 5}$ \\
\hline
\end{tabular}

Fonte: Dados da pesquisa elaborado pelos autores.

\subsection{Perfil dos entrevistados}

O primeiro tópico de perguntas do referido questionário atentou-se em cumprir @no primeiro objetivo específico do trabalho, que baseava-se em identificar o perfil socioeconômico dos discentes que participaram da pesquisa.

Primeiramente, buscou-se saber a quantidade de alunos que participaram da pesquisa de acordo com cada bloco. Logo abaixo na Tabela 2 demonstra os blocos matriculados, respectivos da quantidade de alunos de cada turma e o total de alunos participantes da pesquisa.

Tabela 2 - Bloco matriculado

\begin{tabular}{cccc}
\hline Bloco Matriculado & $\begin{array}{c}\text { Quantidade de } \\
\text { alunos }\end{array}$ & Participantes & $\begin{array}{c}\text { Porcentagem dos } \\
\text { participantes }\end{array}$ \\
\hline II & 27 & 22 & $21,6 \%$ \\
\hline IV & 25 & 14 & $13,7 \%$ \\
\hline V & 22 & 19 & $18,6 \%$ \\
\hline VI & 18 & 17 & $29,4 \%$ \\
\hline VIII & 31 & 30 & $\mathbf{1 0 0 \%}$ \\
\hline Total & $\mathbf{1 2 3}$ & $\mathbf{1 0 2}$ & $16 \%$ \\
\hline
\end{tabular}

Fonte: Dados da pesquisa elaborado pelos autores.

Verifica-se que a amostra foi enviada para 123 alunos e obtivemos resposta de 102 discentes do curso de Ciências Contábeis da UESPI, campus Picos. Tendo como maiores participações o II bloco com 21,6\% e o VIII bloco com $29,4 \%$ dos alunos, isso se processa, por serem os blocos com maiores quantidades de alunos do curso. No total, a pesquisa obteve uma boa participação dos acadêmicos, o que foi bom para alcançar o resultado desejado com maior precisão.

Logo depois, buscou-se identificar o perfil dos entrevistados analisando as características pessoais e financeiras dos mesmos, com o objetivo de conhecer quem foram os participantes da pesquisa, e entender a sua postura de comportamento diante dos conhecimentos das finanças pessoais, de acordo com a Tabela 3 abaixo. 
Tabela 3 - Perfil dos entrevistados.

\begin{tabular}{|c|c|c|c|}
\hline Perguntas & Alternativas & $\begin{array}{c}\text { Total de } \\
\text { Participante }\end{array}$ & Percentual \\
\hline Gênero & $\begin{array}{l}\text { Feminino } \\
\text { Masculino }\end{array}$ & $\begin{array}{l}53 \\
49\end{array}$ & $\begin{array}{l}52 \% \\
48 \%\end{array}$ \\
\hline Faixa Etária & $\begin{array}{l}20 \text { a } 25 \text { anos } \\
16 \text { a } 20 \text { anos } \\
25 \text { a } 30 \text { anos Acima de } \\
30 \text { anos }\end{array}$ & $\begin{array}{l}67 \\
15 \\
15 \\
5\end{array}$ & $\begin{array}{r}65,7 \% \\
14,7 \% \\
14,7 \% \\
4,9 \%\end{array}$ \\
\hline Estado civil & $\begin{array}{l}\text { Solteiro(a) } \\
\text { Casado(a)/União Estável } \\
\text { Divorciado(a)/Separado (a) }\end{array}$ & $\begin{array}{l}87 \\
14 \\
1\end{array}$ & $\begin{array}{c}85,3 \% \\
13,7 \% \\
1,0 \%\end{array}$ \\
\hline $\begin{array}{l}\text { Sua renda é provenientede que } \\
\text { tipo? }\end{array}$ & $\begin{array}{l}\text { Empregado Outros } \\
\text { Autônomo Mesada } \\
\text { dos pais } \\
\text { Empresário }\end{array}$ & $\begin{array}{c}33 \\
32 \\
20 \\
15 \\
2\end{array}$ & $\begin{array}{c}32,3 \% \\
31,4 \% \\
19,6 \% \\
14,7 \% \\
2 \%\end{array}$ \\
\hline Qual sua renda mensal? & $\begin{array}{l}\text { Até um salário mínimo } \\
\text { De um a dois salário mínimosDe dois a } \\
\text { três salário mínimos } \\
\text { Acima de três salário mínimos }\end{array}$ & $\begin{array}{l}78 \\
15 \\
3 \\
6\end{array}$ & $\begin{array}{r}76,5 \% \\
14,7 \% \\
2,9 \% \\
5,9 \%\end{array}$ \\
\hline
\end{tabular}

Fonte: Dados da pesquisa elaborado pelos autores.

Verifica-se, diante dos dados apresentados, que a maioria é do gênero feminino $52 \%$, e apenas $48 \%$ são do gênero masculino. Surpreendendo, pois a grande maioria dos profissionais da área contábil são do gênero masculino, podendo ser reforçado pelos dados do Concelho Federal de Contabilidade (CFC, 2021). No entanto, a representatividade da mulher em altos cargos vem aumentando ao longo dos anos, como podemos perceber através deste resultado da pesquisa, com estudantes que vão se tornar um profissional da área contábil.

Quanto à faixa etária, a maioria tem entre 20 e 25 anos (65,7\%). Como previsto para um público jovem, o estado civil solteiro corresponde à maior parte da amostra $(85,3 \%)$.

Identifica-se que 32,3\% recebe renda através de vínculo empregatício equase o mesmo percentual respondeu ter outro tipo de renda $(31,4 \%)$, destaca-se que todos os participantes possuem algum tipo de renda. Observa-se que mais da metade dos alunos (76,5\%), possuem até um salário mínimo, considerado razoável, pois considera-se que ainda são estudantes e a maioria é bastante jovens. Após a definição do perfil dos alunos, buscou-se um maior aprofundamento quanto ao conhecimento financeiro dos acadêmicos, conforme apresenta a próxima seção.

\subsection{Conhecimento financeiro}

Neste tópico continuaremos cumprindo com o primeiro objetivo específico deste trabalho, apresentando os conhecimentos financeiros dos participantes acerca das Finanças Pessoais e da Educação Financeira.

O Gráfico 1 demonstra os dados obtidos dos discentes relacionados ao conhecimento sobre Finanças Pessoais. 
Gráfico 1 - Você tem conhecimento sobre finanças pessoais?

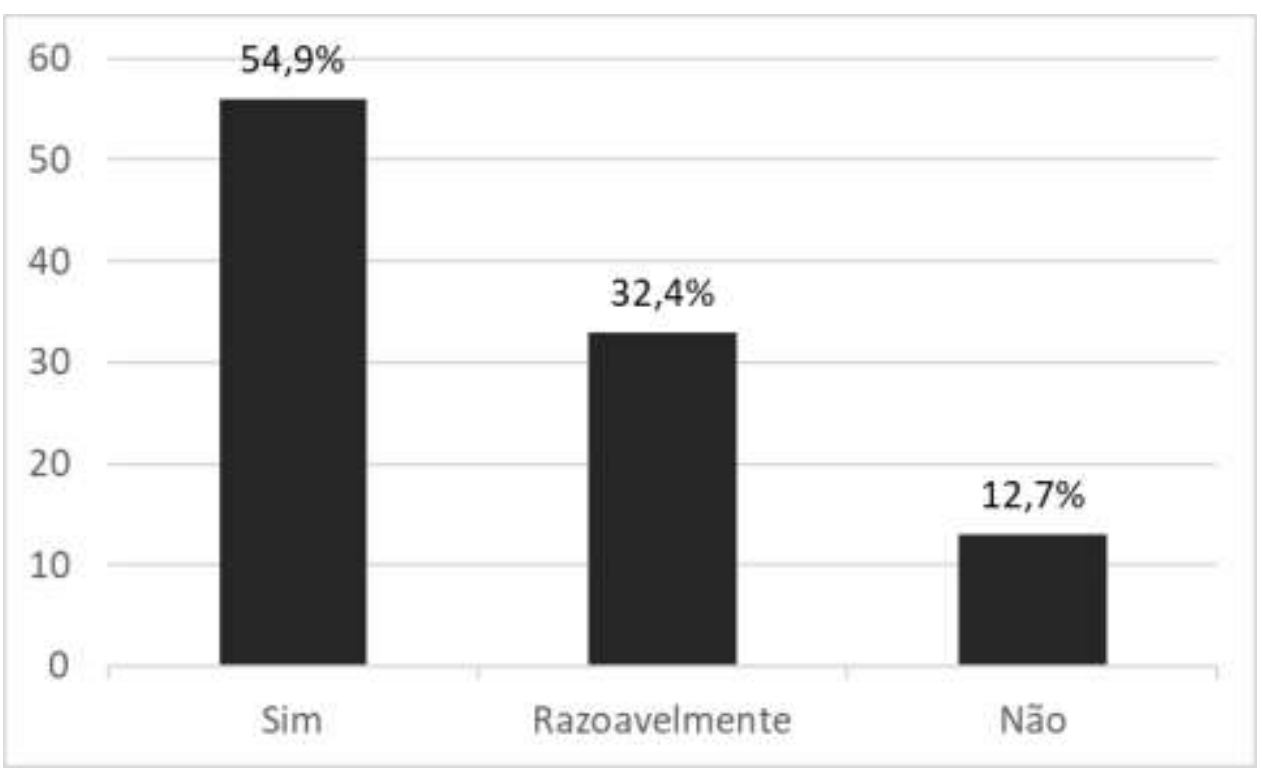

Fonte: Dados da pesquisa elaborado pelos autores.

Questionados se tinham conhecimento sobre finanças pessoais, 54,9\% dos alunos disseram ter conhecimento, 32,4\% conhecem razoavelmente e $12,7 \%$ dos discentes não têm nenhum conhecimento. Neste contexto, é possível identificar que a maioria tem conhecimento para gerenciar suas finanças, porém não é possível afirmar que conhecem tudo sobre Finanças Pessoais.

No trabalho de Radaelli (2018), efetuou-se estudo semelhante, com alternativas que variavam de 1 a 5 , onde 1 significa não ter nenhum conhecimento e5ter conhecimento sólido no assunto. Como resultado, obteve-se que os alunos em sua maioria indicaram ter grau de conhecimento 4 evidenciado por 53,8\% dos respondentes, seguido por 33,7\% indicando grau de conhecimento 3, após 9,6\% @ngrau de conhecimento 5, seguido por 1,9\% indicando grau de conhecimento 2 e $1 \%$ indicaram grau de conhecimento 1. Nesta pesquisa, pode-se constatar que os alunos tinham um maior grau de conhecimento sobre Finanças Pessoais.

Segundo Filho (2003), os conhecimentos básicos de Finanças Pessoais não devem ficar restritos aos especialistas da área financeira, podendo qualquer pessoa ter conhecimento, independentemente de sua atividade profissional. Grande parte da população não está interessada em conhecer finanças, achando que somente importa para os profissionais que lidam com dinheiro.

No Gráfico 2 demonstra os dados obtidos dos discentes em relação à Educação Financeira, se já ouviram falar ou se já recebeu informações sobre a mesma. 
Gráfico 2 - Você já ouviu falar ou recebeu informações sobre Educação Financeira, seja ela em casa, na escola, em palestras ou em algum outro lugar?

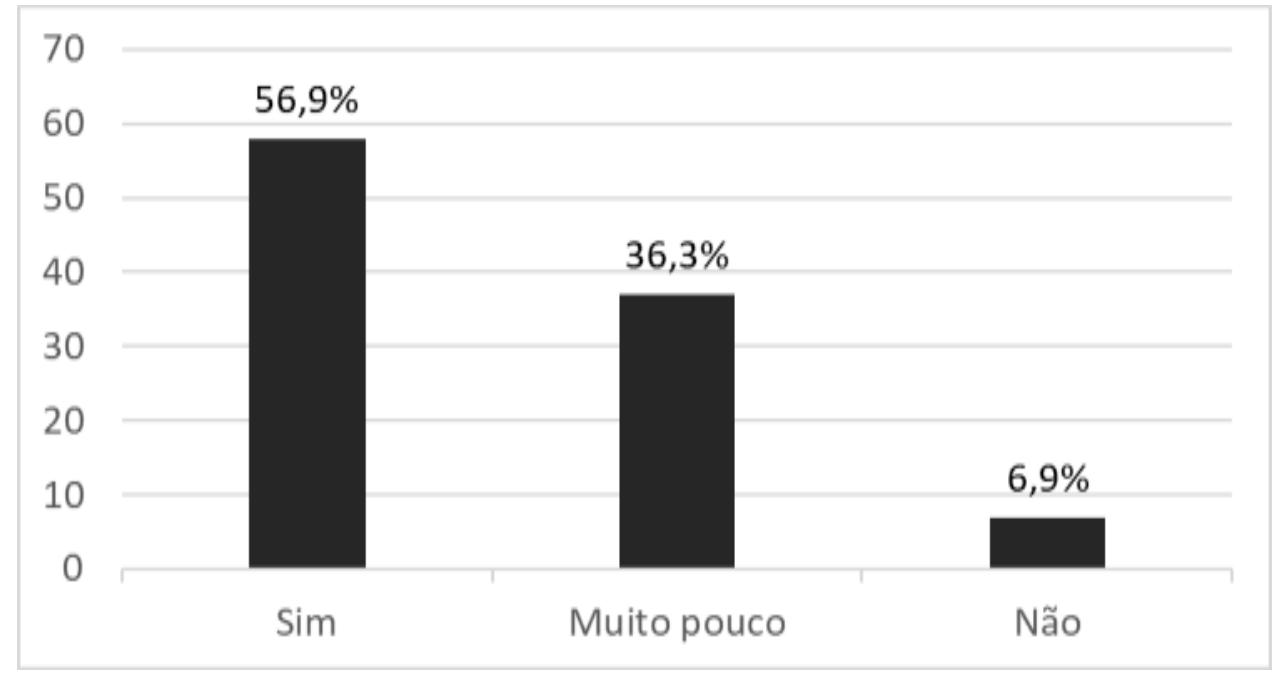

Fonte: Dados da pesquisa elaborados pelos autores.

De acordo com as informações apresentadas, 56,9\% dos alunos já ouviram falar ou receberam informações sobre Educação Financeira, e 36,3\% diz ter ouvido muito pouco, já 6,9\% não ouviu e nem recebeu informações sobre o assunto. Diante dos resultados, percebe-se que a maior parte dos discentes tem conhecimento ou já ouviu falar de alguma forma sobre Educação Financeira, o que torna um resultado satisfatório, pois os alunos estão muito ligados na forma de cuidar das finanças.

Pode-se comparar o resultado obtido ao da análise de Sales (2018), onde 84\% afirmaram conhecer ou já ouviram falar em Educação Financeira, e apenas $16 \%$ não conheceram ou nunca ouviram falar sobre o assunto. Nesta pesquisa o resultado também foi satisfatório com a maioria tendo conhecimento sobre Educação Financeira.

Como se observa, ainda existem pessoas que não conhecem sobre Educação Financeira, entende-se que essas pessoas não tiveram nenhum conhecimento sobre o tema, seja em casa, na escola, em palestras ou em qualquer outro lugar, tornando quase impossível manter um equilíbrio financeiro das suas finanças.

No Gráfico 3 perguntou-se aos alunos, qual importância que eles atribuíam a educação financeira.

Gráfico 3 - Qual a importância que você atribui à Educação Financeira?

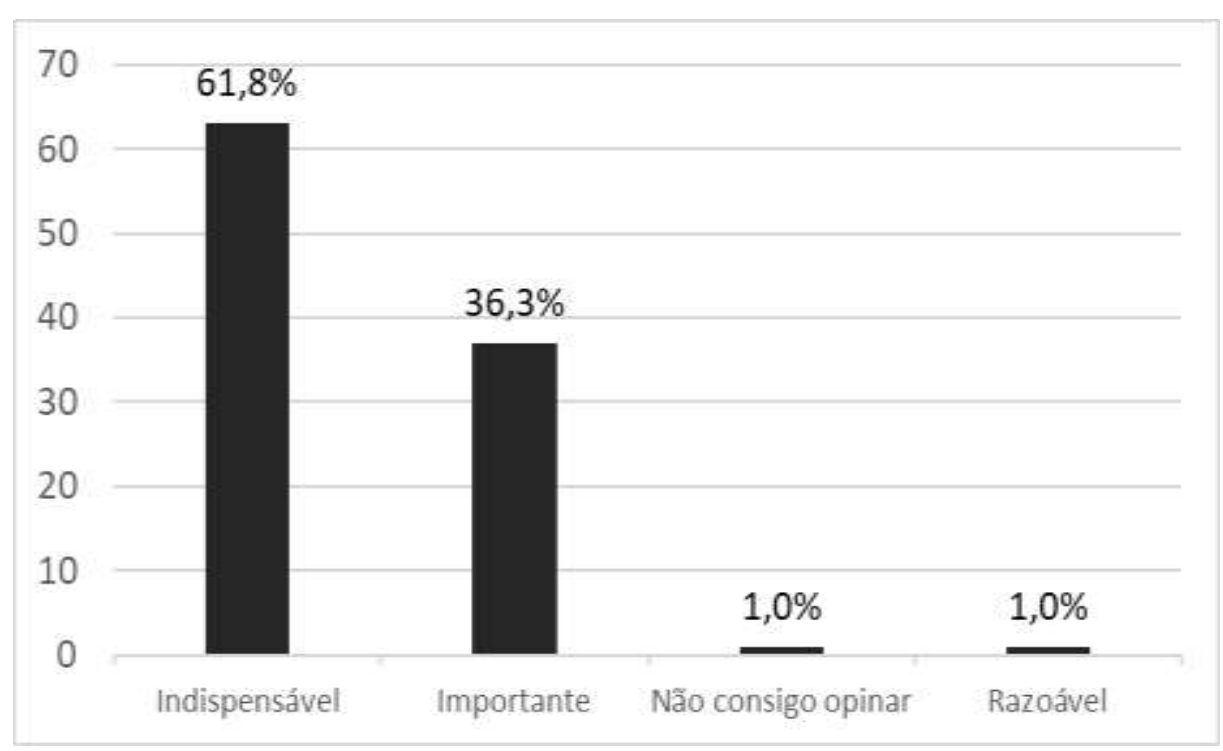

Fonte: Dados da pesquisa elaborados pelos autores. 
Questionados em relação à importância que atribuíam à Educação Financeira, verificou-se que a maior parte $(61,8 \%)$ dos alunos classifica como indispensável, 36,3\% acha importante e apenas $1 \%$ não conseguiu opinar e 1\% considera razoável. Verifica-se desta forma que nenhum dos alunos acha desnecessário a importância da Educação Financeira.

A amostra identifica que a Educação Financeira para a maioria é indispensável na obtenção de uma vida financeira melhor, sendo indispensável no gerenciamento do seu dinheiro ao longo da vida. Com esses dados observa-se que mesmo os alunos que nunca tinham ouvido falar sobre o tema têm consciência queo mesmo é de suma importância.

Tais resultados também são evidenciados no trabalho de Barreto (2013), que obteve resultados aproximadamente iguais segundo a análise da pesquisadora, não foi obtido nenhuma resposta que a Educação Financeira é pouco importante ou irrelevante, ou seja, a amostra identificou que a Educação Financeira é algo bem relevante para a obtenção de uma relação melhor de custos versus benefícios na hora de investir.

Apresentado o grau de importância quanto à Educação Financeira, verifica-se na próxima seção como os alunos fazem seu planejamento financeiro.

\subsection{Planejamento financeiro}

Nesta fase da pesquisa buscou-se atender o segundo objetivo específico deste trabalho, que trata do planejamento financeiro, se fazem uso ou não dessa ferramenta. A primeira questão relacionada ao assunto era verificar se os alunos costumam se planejar antes de gastar o dinheiro. Como mostra no Gráfico 4 abaixo.

Gráfico 4 - Você costuma se planejar antes de gastar seu dinheiro?

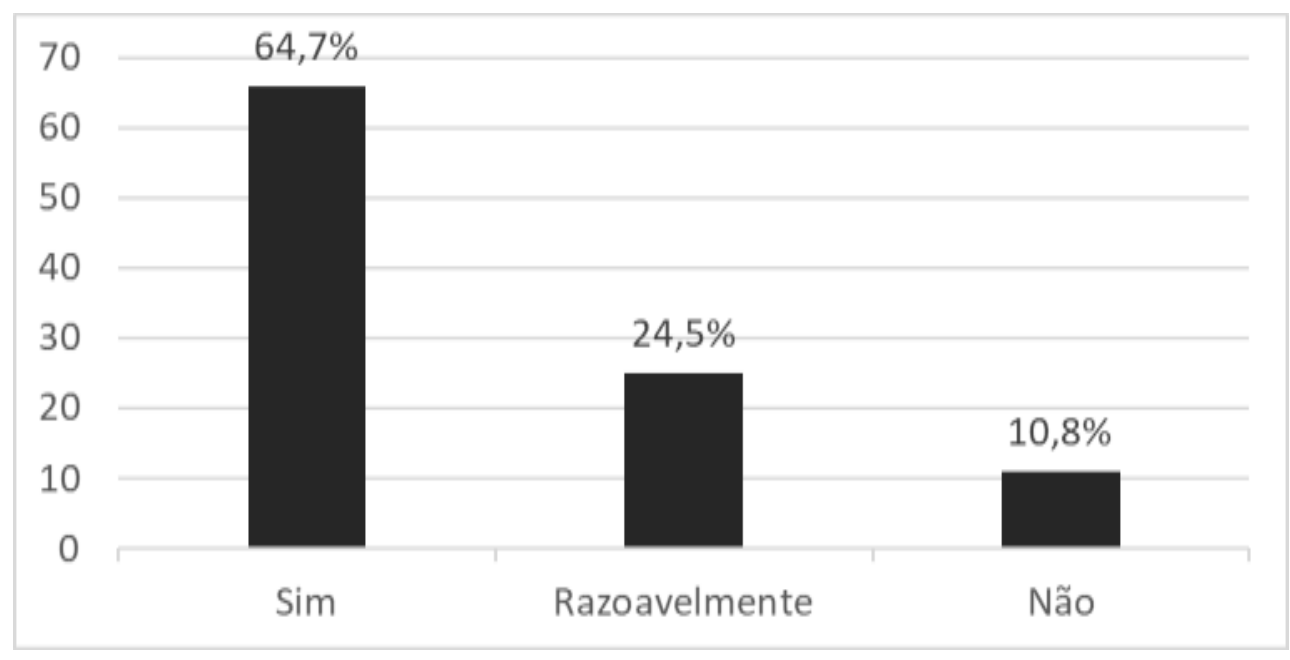

Fonte: Dados da pesquisa elaborados pelos autores.

Observou-se que um total de $64,7 \%$ se planeja, já $24,5 \%$ diz que se planeja razoavelmente e $10,8 \%$ não faz planejamento. Identifica-se que os alunos têm visão de administração do dinheiro pois a maioria costuma se planejar antes de gastar, o que é muito bom diante dos resultados que pretendemos alcançar pois sempre que fazemos um planejamento teremos grandes possibilidades de obter êxito.

Um resultado similar foi obtido no trabalho de Sales (2018), questionados se os alunos planejavam seus gastos, verificou-se que $65,45 \%$ dos alunos planejam seus gastos, enquanto $34,55 \%$ dos alunos alegaram não realizar seu planejamento financeiro pessoal. Assim faz referência com nossa pergunta e resposta obtida.

De acordo com Sousa, et al., (2018), o planejamento é apontado como a ferramenta de maior importância para alcançar objetivos e se faz necessário em todas as áreas, principalmente nas Finanças Pessoais, com objetivo de atingir a independência financeira. 
Questionou-se aos acadêmicos se os mesmos sabiam fazer um planejamento financeiro como mostra o Gráfico 5.

Gráfico 5 - Você sabe como faz um Planejamento Financeiro?

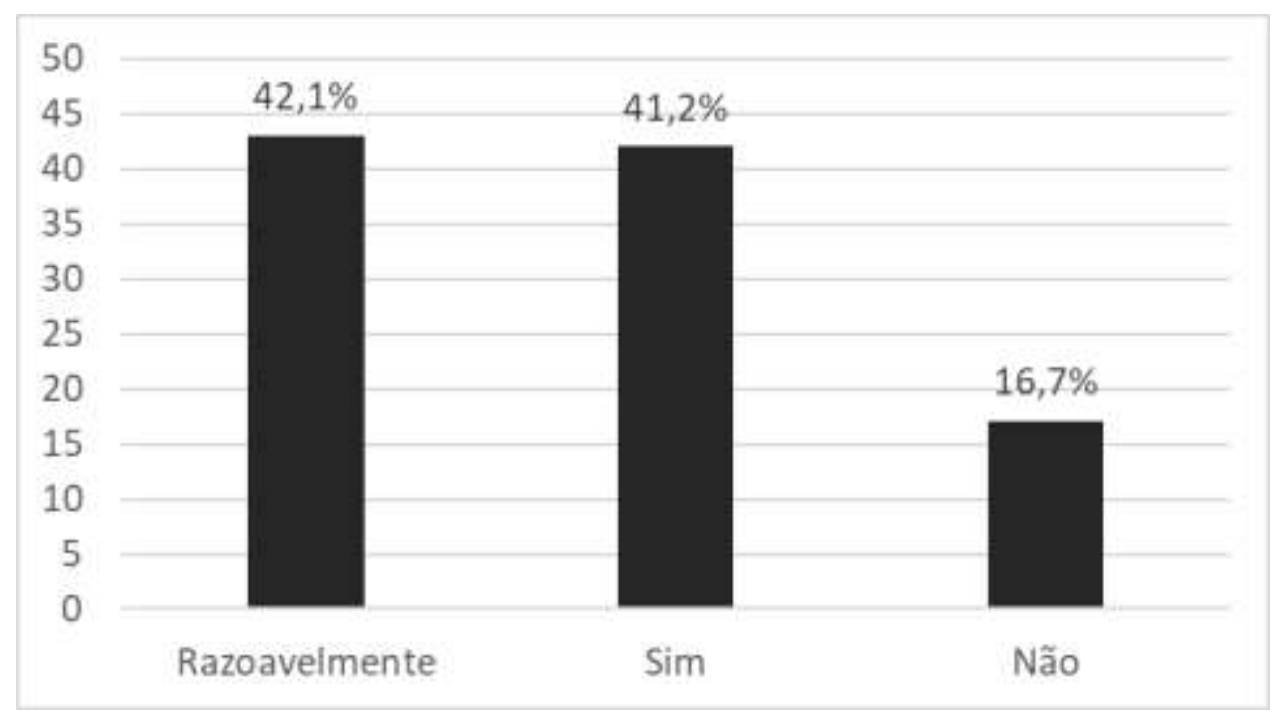

Fonte: Dados da pesquisa elaborados pelos autores.

De acordo com a pesquisa, identifica-se que a maioria $(42,1 \%)$ sabe razoavelmente fazer um planejamento, porém existe quase o mesmo total de alunos $(41,2 \%)$ que diz sabe fazer, e $16,7 \%$ dos alunos indica não saber fazer um planejamento. Como percebe-se praticamente quase todos os participantes sabem de alguma forma fazer um planejamento financeiro, mesmo a maioria que respondeu "razoavelmente" faz de alguma forma o seu planejamento.

No livro de Cherobim \& Espejo (2011), relata que fazer um Planejamento Financeiro Pessoal é de suma importância para que possa tomar decisões antecipadamente, reduzindo os riscos que possam afetar as finanças, possibilitandooalcance de metas e de sonhos. Segundo o mesmo fazer um planejamento pessoal está relacionado com os objetivos que cada pessoa tem na vida.

Diante disso, o planejamento é indispensável na vida das pessoas, pois possibilita saber, com antecedência, que caminhos estão sendo trilhados, visando maximizar os resultados econômico-financeiros.

Logo após, os alunos foram indagados como eles fazem o seu planejamento conforme indica no Gráfico 6.

Gráfico 6 - Como você faz seu planejamento?

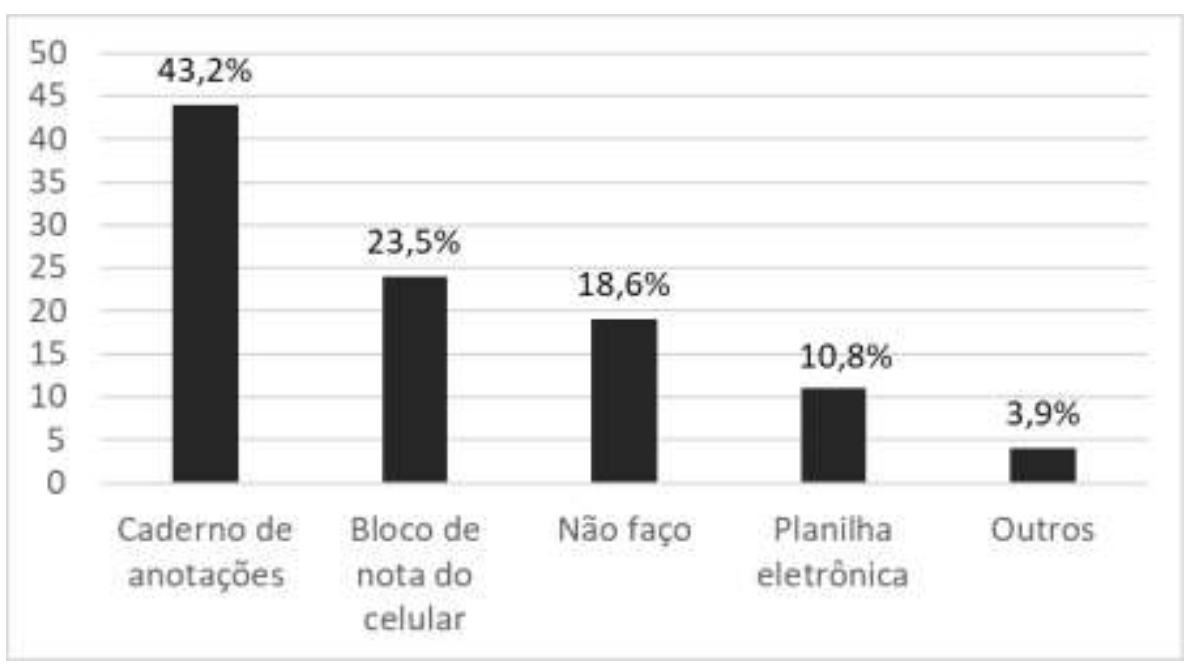

Fonte: Dados da pesquisa elaborados pelos autores. 
Percebe-se que 43,2\% dos acadêmicos de contábeis respondeu que fazem o Planejamento Financeiro em caderno de anotação, 23,5\% no bloco de nota do celular, 18,6\% não faz em nenhum lugar, 10,8\% utiliza planilha eletrônica e 3,9\% fazem em outro local. Verifica-se que a maioria dos alunos costuma fazer o planejamento em cadernos e em bloco de nota do celular, e os que não fazem são quase o mesmo percentual da resposta anterior dos que não sabem fazer um planejamento financeiro.

De acordo com o Banco Central do Brasil (2013), é necessário ter um controle das receitas e despesas, assim como se organizar e definir o que tem de ser feito, de modo que a menos tempo e menor custo alcançasse os objetivos possível. Logo, para se ter esse controle é necessário a realização do planejamento financeiroem uma ferramenta mesmo que simples do que não se planejar.

Analisado o resultado referente aos objetivos mencionados no início da seção, a próxima visa saber se os alunos usam as técnicas contábeis aprendidas no curso e se levaram esse aprendizado pra vida em relação ao futuro financeiro.

\subsection{Utilização das técnicas contábeis no Planejamento financeiro}

Por fim o último tópico de perguntas buscou responder o último objetivo específico do referido trabalho, que era identificar a importância da contabilidade eædemonstrações contábeis dentro das finanças pessoais dos discentes do curso de Ciências Contábeis.

Primeiramente, os alunos foram questionados em relação às técnicas contábeis usadas no planejamento financeiro, ao qual queria saber se eles fazem uso das técnicas contábeis no planejamento financeiro. Conforme exposto abaixo no Gráfico 7.

Gráfico 7 - Você faz uso das técnicas contábeis no seu planejamento financeiro?

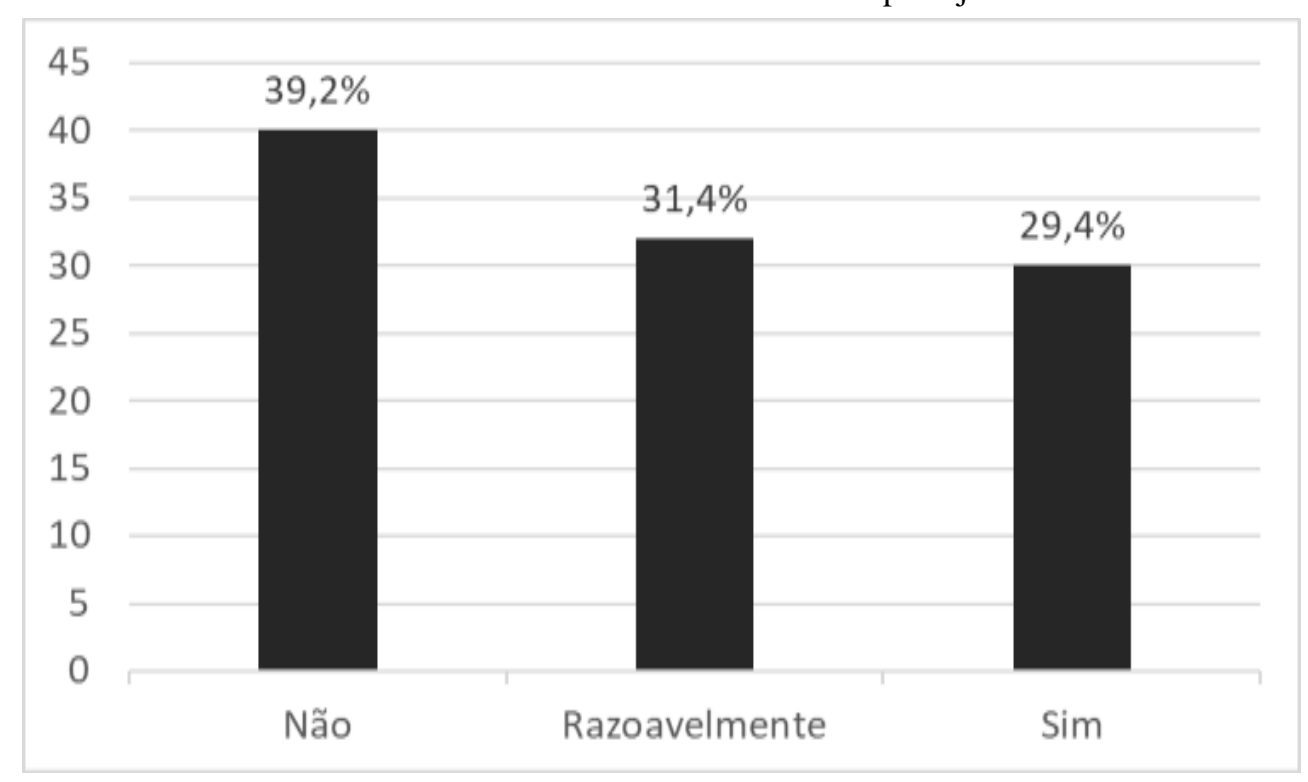

Fonte: Dados da pesquisa elaborados pelos autores.

Na coleta verificou-se que 39,2\% dos alunos não faz uso, 31,4\% usa razoavelmente e apenas $29,4 \%$ faz uso das técnicas contábeis. Nota-se, dessa forma, que a maioria não usa as técnicas contábeis, o que nos surpreendeu, pois os alunos, mesmo com conhecimento na área contábil, não fazem uso dela no seu planejamento financeiro. No entanto esse resultado deve ter ocasionado devido uma maioria dos participantes ser do II Bloco e os mesmos não ter muito conhecimento sobre o uso das técnicas contábeis e da sua importância dentro do planejamento financeiro, devido serem alunos novos e não ter visto conteúdos sobre o assunto. 
No seu livro de Bodie \& Merton (2002) relata que a aplicação das técnicas contábeis em sua gestão pessoal aumenta suas chances de sucesso financeiro que visualiza a Ciência Contábil sendo aplicada na prática. Para o autor elas atendem a três importantes funções econômicas: proporcionam informações sobre a posição atual e o desempenho financeiro, são usadas para estabelecer metas de desempenho, e proporcionam modelos para o planejamento financeiro.

Ainda buscando atender o proposto do trabalho, os alunos foram questionados sobre quais eram as técnicas contábeis que os mesmos utilizam no planejamento. Os resultados obtidos observam-se no Gráfico 8:

Gráfico 8 - Em relação à pergunta anterior, quais técnicas contábeis você utiliza em seu planejamento financeiro?

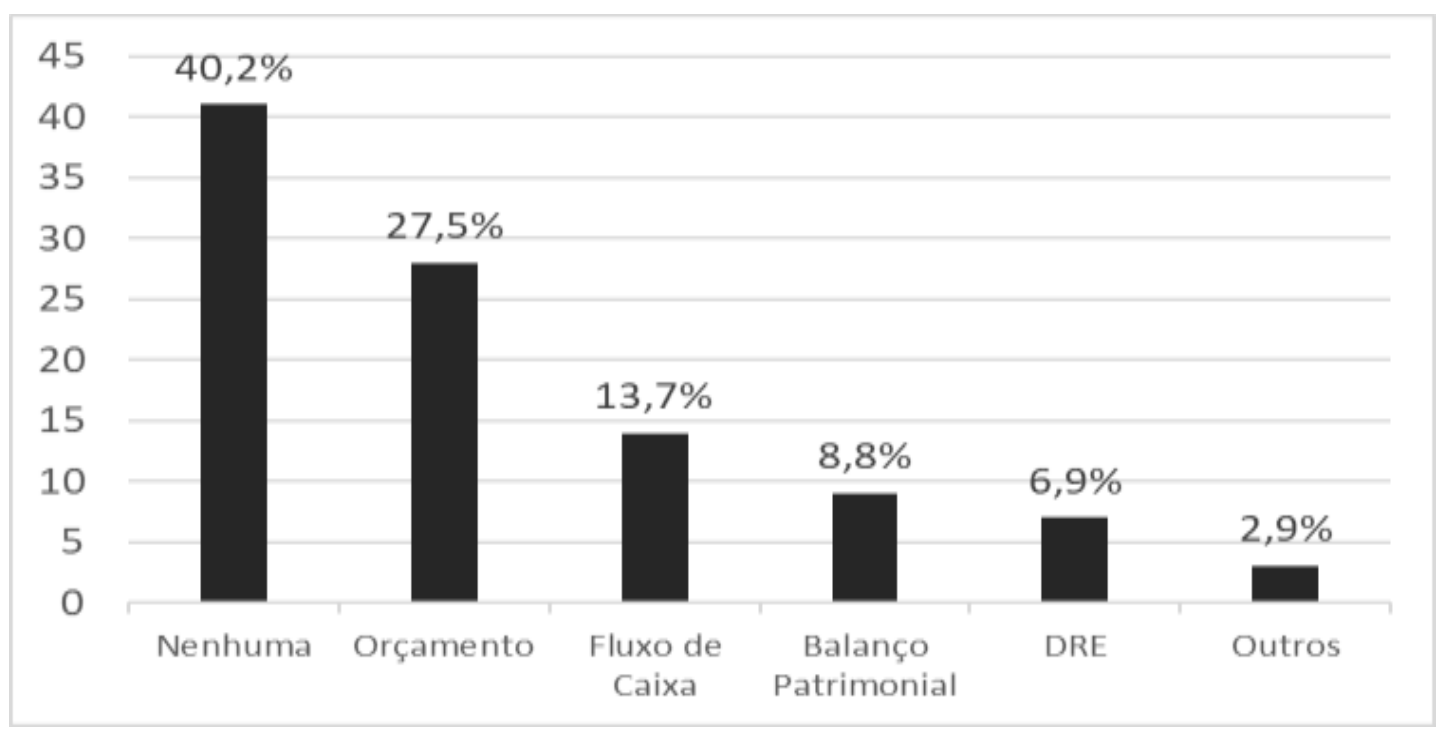

Fonte: Dados da pesquisa elaborados pelos autores.

Observa-se que 40,2\% indicou não usar nenhuma técnica contábil no seu planejamento financeiro, já 27,5\% utiliza o orçamento, $13,7 \%$ faz uso do fluxo de caixa, 8,8\% usa o balaço patrimonial, 6,9\% usa a DRE e 2,9\% dos alunos marcou a opção "outros", dando a entender quer faz uso de outra técnica contábil que não foi citada.

Verifica-se que as ferramentas contábeis mais utilizadas foram o orçamento e fluxo de caixa e que a maioria dos alunos não utiliza nenhuma demonstração contábil no planejamento financeiro, como já previsto devido a questão anterior, pois a maioria dos alunos não usa as técnicas contábil no seu planejamento financeiro.

O mesmo resultado também foi obtido no trabalho de Henn (2015), que foi verificado mais da metade (62\%) dos participantes não utilizam nenhuma ferramenta contábil para o controle e planejamento financeiro pessoal e os mais usados tambémforam o orçamento e fluxo de caixa.

Nesse sentido, Iudícibus (2009) enfatiza que frequentemente as pessoas se esquecem de que o uso das técnicas Contábeis pode contribuir muito no controle, planejamento, ordem e equilíbrio de seus orçamentos.

Por fim, os acadêmicos foram questionados se consideram que o conhecimento contábil adquirido no curso de contábeis da UESPI ajudara eles a terem uma vida financeira equilibrada. 
Gráfico 9 - Você considera que o conhecimento contábil adquirido na UESPI poderálhe auxiliar para ter uma vida financeira equilibrada?

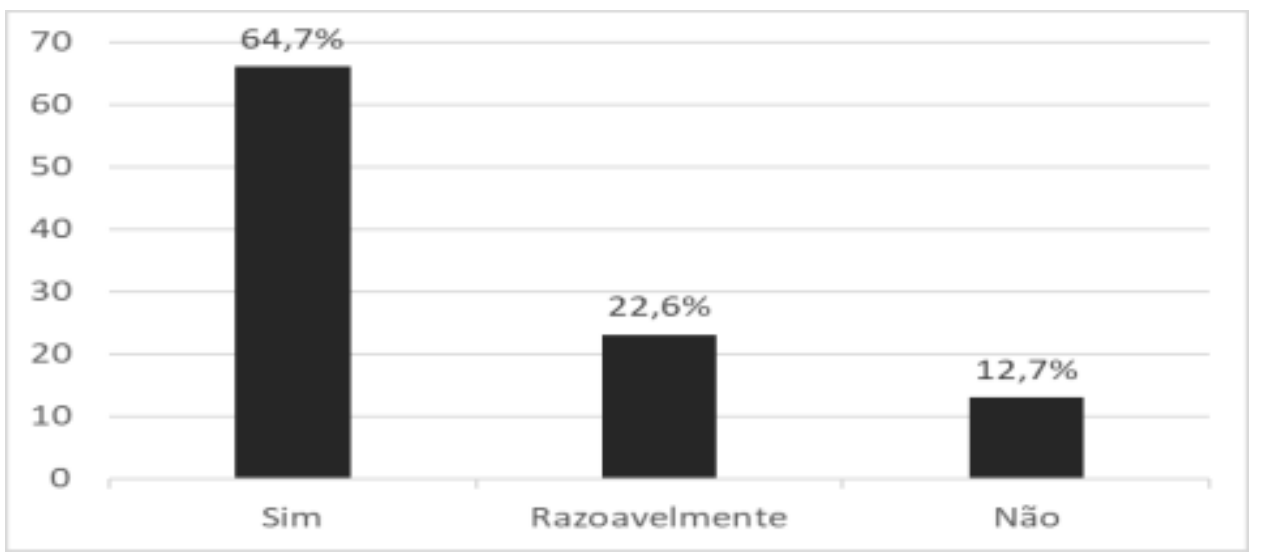

Fonte: Dados da pesquisa elaborados pelos autores.

Percebe-se que a grande maioria 64,7\% considera importância, já 22,6\% considera razoável e 12,7\% não considera necessário o conhecimento contábil no auxílio para ter uma vida financeira equilibrada. Obteve-se um resultado bastante satisfatório pois a maioria dos discentes afirma que o conhecimento contábil poderá auxiliá-los para ter uma vida financeira equilibrada. Percebesse que mesmo esses alunos não fazendo uso das técnicas contábeis, eles têm consciência que o conhecimento contábil é importante. Confirmando o aprendizado do curso, que servirá para a vida financeira dos acadêmicos.

Os resultados apurados por Henn (2015) em um questionamento semelhante afirmam que 95\% reconhecem a importância e 5\% não considera necessário o uso da Contabilidade para ter uma vida financeira equilibrada.

Kiyosaki \& Lechter (2001) afirmam que assuntos como Contabilidade são importantes para a vida das pessoas, porém muitos sabem pouco sobre esses assuntos, pois as escolas e universidades se concentram nas habilidades acadêmicas e profissionais, mas não nas habilidades financeiras.

\section{Considerações Finais}

De acordo com os estudos realizados e com base na pesquisa de campo, buscou-se identificar se os acadêmicos do curso de Ciências Contábeis da UESPI, campus Professor Barros Araújo, da cidade de Picos, usavam o planejamento financeira e as técnicas contábeis dentro das suas finanças.

Dessa forma, identificou-se que conhecer as Finanças Pessoais é fundamental na tomada de decisões e controle para ter uma vida financeira tranquila e equilibrada. No que diz respeito ao Planejamento Financeiro percebe-se queaplicado nas finanças, terá um controle de todo seu dinheiro, com condições para ter uma qualidade de vida melhor, através da realização pessoal e profissional. É perceptível também que as demonstrações contábeis são essenciais no auxílio do processo do planejamento das finanças pessoas. Neste contexto, apresentou-se a teoria com conceito e modelo das demonstrações contábeis-financeiras pessoais para que possam ser usados pelos acadêmicos, entre as quais mais usadas pelos participantes através da pesquisa, foram o orçamento e o fluxo de caixa.

Em relação às questões conceituais, para que fosse possível alcançar os objetivos do trabalho, foi aplicado aos alunos um questionário, com base na temática abordada e através dos resultados obtidos foi possível alcançar os objetivos deste trabalho que foi extremamente satisfatório para minha pesquisa.

Por conseguinte, os objetivos da pesquisa foram atingidos ao concluir-se que os alunos apresentam um bom nível de conhecimento sobre o tema abordado, pois segundo as análises realizadas, a maioria afirma conhecer Finanças Pessoais e já 
ouviram sobre Educação Financeira como também mais da metade acha indispensável o uso da mesma. Sobre Planejamento Financeiro, mais da metade demonstrou que costuma se planejar antes de gastar e afirmam saber fazer um planejamento mesmo que seja simples. Em relação à utilização das técnicas contábeis no planejamento financeiro, a maioria não faz uso de tais técnicas, mas acha importante o conhecimento contábil adquirido da UESPI para ter uma vida financeira equilibrada. Concluindo assim, que mesmo não fazendo uso das técnicas contábeis no planejamento financeiro pessoal, a grande maioria dos alunos considera importante o uso delas pois no planejamento das finanças pessoais são essenciais e grandes aliadas se usadas corretamente.

O trabalho elaborado contribuiu para meu crescimento pessoal e formação profissional, pois conhecendo sobre a temática e o que os alunos relataram em relação ao conhecimento financeiro foi possível perceber que os alunos tem conhecimento sobre o tema e que os mesmos serão capazes de administrar seu patrimônio e aplicar o planejamento financeiro em suas fianças pessoais.

Diante destes resultados, entende-se que os objetivos definidos foram cumpridos, contudo vale ressaltar que existem limitações no estudo e que estas conclusões estão limitadas somente à amostra dos alunos de Ciências Contábeis da UESPI de Picos que participaram desta pesquisa, e não podem ser generalizados.

\section{Referências}

Banco Central do Brasil. (2013). Caderno de educação financeira - gestão definanças pessoais. Brasília: BCB.

Bardin, L. (2011). Análise de conteúdo. São Paulo: Edições 70.

Barreto, K. O. M. (2013). Educação financeira: um estudo sobre sua importância para investidores da cidade de criciúma e região. Trabalho de conclusão de curso (Ciências Econômicas) - Universidade Federal de Santa Catarina. Florianópolis, 2013. https://repositorio.ufsc.br/bitstream/handle/123456789/103820/ Monografia\%20da\%20Katarine\%200limpio\%20ManiqueBarreto.pdf?sequence=1.

Bodie, Z \& Merton, R. C. (2002). Finanças. Porto Alegre: Bookman.

BM \& FBOVESPA. Orçamento pessoal.http://03_Planilha_BMeFBovespa_OrcamentoPessoalEdu.

Cerbasi, G. (2015). Como organizar sua vida financeira. Rio de Janeiro: Sextante.

Cherobim, A. P. M. S. \& Espejo, M. M. S. B. (2011). Finanças pessoais: conhecer paraenriquecer. São Paulo: Atlas.

CFC - Conselho Federal de Contabilidade. Profissionais Ativos nos Conselhos Regionais de Contabilidade agrupados por Gênero. https://www3.cfc.org.br/spw/crcs/ConsultaPorRegiao.aspx?Tipo=0.

Domingos, R. (2013). Sabedoria financeira: o milagre da multiplicação de seus recursos.São Paulo: Thomas Nelson Brasil.

Ferreira, R. (2006). Como planejar, organizar e controlar seu dinheiro: manual de finanças pessoais. São Paulo: Editora IOB Thomson.

Frankenberg, L. (1999). Seu futuro financeiro, você é o maior responsável: comoplanejar suas finanças pessoais para toda a vida. Rio de Janeiro: Campus.

Gil, A. C. (2008). Métodos e técnicas de Pesquisa Social. São Paulo: Atlas.

Gitman, L. J. (2004). Princípios de administração financeira. São Paulo: PearsonAddison Wesley.

Gallagher, L. (2008). Planeje seu futuro financeiro: o guia sobre investimentos paramultiplicar seu patrimônio. Rio de Janeiro: Elsevier.

Goldenberg, M. (2004). A arte de pesquisar: como fazer pesquisa qualitativa emciências sociais. Rio de Janeiro: Record.

Halfed, M. (2007). Investimentos: como administrar melhor seu dinheiro.SãoPaulo: Fundamento.

Henn. J. (2015). A aplicabilidade dos conceitos e técnicas da contabilidade nas finanças pessoais: estudo realizado com os acadêmicos formandos de ciências contábeis. Trabalho de Conclusão do Curso (Graduação em Ciências Contábeis) Universidade do Extremo Sul Catarinense, Criciúma, 2015. http://repositorio.unesc.net/bitstream/1/3576/1/Jaine\%20Henn.pdf.

Kiyosaki, R T. \& Lechter, S L. (2001). Independência financeira: o guia do pai rico. Rio de Janeiro: Campus.

Iudícibus, S. (2009). Teoria da Contabilidade. São Paulo: Atlas.

Iudícibus, S. et al. (2010). Contabilidade Introdutória. São Paulo: Atlas.

Iudícibus, S. et al. (2007). Manual de Contabilidade das Sociedades por Ações: Aplicável a demais sociedades. São Paulo: Atlas. 
Research, Society and Development, v. 10, n. 7, e50310716879, 2021

(CC BY 4.0) | ISSN 2525-3409 | DOI: http://dx.doi.org/10.33448/rsd-v10i7.16879

Kotler, P. \& Keller, K. L. (2006). Administração de marketing. São Paulo:Pearson.

Macedo Júnior, J. S. (2013). A árvore do dinheiro: guia para cultivar a suaindependência financeira. Florianópolis: Insular.

Marion, J. C. (2018). Contabilidade básica. São Paulo: Atlas.

Marion, J. C. (2018). Contabilidade empresarial: instrumentos de análise, gerência edecisão. São Paulo: Atlas.

Martins, G. A. \& Theóphilo, C. R. (2009). Metodologia da investigação científica para ciências sociais aplicadas. São Paulo: Atlas.

Massaro, A. (2015). Guia de educação financeira no ambiente de trabalho. E- book. https://www.andremassaro.com.br/gefat/.

Montoto, E. (2015). Contabilidade geral e avançada. São Paulo: Saraiva.

Parasuraman, A. (1991). Marketing research. New York: Addison-WesleyPublishing Company.

Pereira, G. M. G. (2005). As personalidades do dinheiro: como lidar com o dinheiro deacordo comseu estilo pessoal. Rio de Janeiro: Elsevier.

Pires, V. (2006). Finanças pessoais: Fundamentos e Dicas. Piracicaba: Equilíbrio.

Prodanov, C. C. \& Freitas, E. C. (2013). Metodologia do Trabalho Científico: métodose técnicas da pesquisa e do trabalho acadêmico.Novo Hamburgo: Feevale.

Radaelli, F. (2018). Estudo sobre as finanças pessoais dos alunos de ciências contábeis de uma instituição de ensino superior do vale do taquari. Monografia (Graduação em Ciências Contábeis) - Universidade do Vale do Taquari, Lajeado, 2018. https://www.univates.br/bdu/bitstream/10737/2090/ 1/2018Fab\%C3\%ADolaRadaelli.pdf.

Ribeiro, O. M. (2010). Contabilidade geral fácil. São Paulo: Saraiva.

Sales, V. K. O. (2018). A Educação financeira no contexto do aprendizado escolar: um estudo com alunos do ensino fundamental II em uma escola particular no interior de Pernambuco. Trabalho de conclusão de curso (Ciências Contábeis) - Centro de Ciências Sociais Aplicadas, da Universidade Federal da Paraíba, João pessoa, 2018. https://repositorio.ufpb.br/jspui/bitstream/123456789/11889/1/VKOS04102018.pdf.

Santos, J. O. dos. (2009). Análise de crédito: empresas, pessoas físicas, agronegócio e pecuária.São Paulo: Atlas.

Segundo Filho, J. (2003). Finanças Pessoais: invista no seu futuro. Rio de Janeiro:Qualitymark.

Silva, S. A. \& Tristão, G. (2009). Contabilidade básica. São Paulo: Atlas.

Sousa, A. F. et al. (2018). Planejamento financeiro pessoal e gestão do patrimônio: fundamentos e prática. Barueri: Manole.

Tommasi, A.\& Lima, F. (2007). Viva melhor sabendo administrar suas finanças. São Paulo: Saraiva. 